\title{
Evaluation of entomopathogenic fungi as biological control agents Rhipicephalus (Boophilus) microplus (Canestrini, 1887) (Acari: Ixodidae)
}

\author{
Evaluación de hongos entomopatógenos como agentes de control \\ biológico para Rhipicephalus (Boophilus) microplus \\ (Canestrini, 1887) (Acari: Ixodidae) \\ Sônia M. F. Broglio-Micheletti ${ }^{1}$, Leilianne A. de Souza ${ }^{2}$, Ellen C. N. Valente ${ }^{3}$, \\ Mário J. C. de Araújo ${ }^{3}$,Nivia da Silva Dias ${ }^{4}$, Mariuxi Lorena Gómez-Torres ${ }^{5}$
}

\begin{abstract}
The aim of this study was to evaluate in the laboratory different isolates and concentrations of conidia of Metarhizium anisopliae (Metschnikoff, 1879) Sorokin, 1883 and Beauveria bassiana (Balsamo) Vuillemim, 1912 for control of the cattle tick. The conidial suspensions were prepared from fungi grown in rice medium in polypropylene bags. The tests were performed by immersion of engorged females collected from animals not treated with acaricides. The experimental design was completely randomized with 20 treatments and 5 repetitions, each consisting of 5 females. The mortality rate caused by the fungus M. anisopliae ranged from 92 to $100 \%$, while for B. bassiana it was 44 to $100 \%$; mortality was greater at concentrations of $10^{8}$ and $10^{9}$ conidia $\mathrm{mL}^{-1}$ suspension.

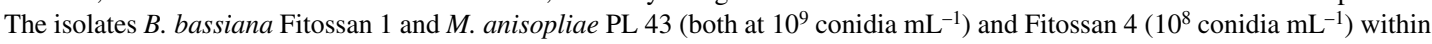
14 days of treatment killed $100 \%, 92 \%$ and $88 \%$ of the engorged females, respectively. In general there was no difference in the weight of eggs from females treated with the same isolate at concentrations of $10^{7}, 10^{8}$ and $10^{9}$ conidia $\mathrm{mL}^{-1}$, although isolates of M. anisopliae had lower weight. The efficiency of control ranged from $0 \%$ (control with water) to $31.30 \%$ (M. anisopliae Fitossan $4,10^{8}$ conidia $\mathrm{mL}^{-1}$ ).
\end{abstract}

Key words: cattle tick, biological control, Metarhizium anisopliae, Beauveria bassiana.

\section{RESUMEN}

El objetivo de este trabajo fue evaluar diferentes colonias aisladas en concentraciones de Metarhizium anisopliae (Metschnikoff, 1879) Sorokin, 1883 y de Beauveria bassiana (Balsamo) Vuillemim, 1912 para el control de la garrapata común del vacuno. La multiplicación de conidias fue realizada a partir de hongos inoculados en arroz precocido estéril. Los ensayos de inmersión fueron realizados sobre garrapatas adultas ingurgitadas o teleoginas colectadas de bovinos no tratados con acaricidas. El diseño experimental fue completamente al azar con 20 tratamientos y cinco repeticiones, siendo cada una de estas constituidas por cinco hembras. La mortalidad de las teleoginas ocasionada por M. anisopliae fue variable entre 92 a $100 \%$ y para $\mathrm{B}$. bassiana este parámetro varió entre 44 a 100\%, observándose que la mortalidad fue superior en las concentraciones de $10^{8}$ y $10^{9} \mathrm{conidias} \mathrm{mL}^{-1}$, destacándose las cepas de B. bassiana Fitossan 1 e M. anisopliae PL 43 (ambos $10^{9}$ conidias $\mathrm{mL}^{-1}$ ) y Fitossan 4 (10 ${ }^{8}$ conidias $\left.m L^{-1}\right)$, que a los 14 días de tratamiento habían eliminado el 100, 92 y $88 \%$ de las teleoginas, respectivamente. En general, no existió diferencia en relación al peso de los huevos provenientes de hembras tratadas con el mismo aislado en las concentraciones de $10^{7}, 10^{8}$ y $10^{9}$ conidia. $\mathrm{mL}^{-1}$, aunque se obtuvieron pesos inferiores para las cepas de M. anisopliae. La eficiencia del control varió de 0\% (control) a 31,30\% (M. anisopliae Fitossan 4, 108 conidias. $m L^{-1}$ ).

Palabras clave: garrapata bovina, control biológico, Metarhizium anisopliae, Beauveria bassiana.

1 Profesora, Centro de Ciências Agrárias, Universidade Federal de Alagoas (CECA, UFAL). Campus Delza Gitaí, Rod. BR 104, Km 85, s/n, Rio Largo, AL, CEP: 57.100-000, telefone: (55)82-3261-1351. soniamfbroglio@ gmail.com

2 Ing. Agrónoma, CECA, UFAL, Rio Largo, AL. leiliannealves@ hotmail.com

3 Candidato (a) a maestría, Universidad Federal Rural de Pernambuco. carineinicial@ hotmail.com; mariojca@gmail.com

4 Doctora en Ciencias. DCR, CECA, UFAL, Rio Largo, AL. e-mail: dias.nivia@gmail.com

5 Doctora en Ciencias. Universidade de São Paulo - Escola Superior de Agricultura "Luiz de Queiroz" (ESALQ - USP). mariuxi. gt10@gmail.com

Fecha de Recepción: 28 Julio, 2009.

Fecha de Aceptación: 07 Marzo, 2012. 


\section{Introduction}

In tropical and subtropical regions the tick Rhipicephalus (Boophilus) microplus (Canestrini, 1887) (Acari: Ixodidae) is the most important ectoparasite in livestock farms, and is responsible for large economic losses (Athayde et al. 2001). As well as producing spoliation, the attack of this species damages the hide of the host and is the principal transmitter of pathogenic agents of cattle (Bittencourt et al. 1999).

The control of the parasitic stages of the tick $R$. microplus uses mainly chemical products applied directly on the animal (Wenzel et al. 2004). Currently, this type of control is producing a progressive increase in the resistance of this ectoparasite, and consequently an increase in the residues of acaricides in milk and meat (Mendes et al. 2007). Studies on $R$. microplus are currently searching for control strategies using a combination of the prudent and rational use of the available acaricides and other forms of control, in order to maintain the parasite populations under the economic damage limit and to produce the minimum environmental impact (FAO 2003). Alternative methods include the use of genetically resistant animals, development of vaccines, management of grasslands with alternation of species and biological control (Leal et al. 2003).

Entomological pathogens are considered to be an important factor in the reduction of pest species; these agents may occur naturally or may be introduced into the agroecosystems (Bahiense et al. 2007). The fungi Metarhizium anisopliae (Metschnikoff, 1879) Sorokin, 1883 (Ascomycota: Nectriaceae) and Beauveria bassiana (Balsamo) Vuillemim, 1912 (Ascomycota: Clavicipitaceae) are promising agents for the biological control of ticks, thus in recent years a number of studies have investigated the relationships between entomopathogenic fungi and different species of tick (Bittencourt et al. 1994, Bittencourt et al. 1996, Bittencourt et al. 1997, Correia et al. 1998, Bittencourt et al. 1999, Frazzon et al. 2000, Bahiense y Bittencourt 2004, Basso et al. 2005, Lopes et al. 2007, Bahiense 2007).

The objective of this study was to evaluate, using immersion tests, different isolates and concentrations of $M$. anisopliae and B. bassiana in terms of the mortality of engorged females, number of eggs laid, egg weight (mg), percentage eclosion and efficiency of the product $(\%)$.

\section{Methods and Materials}

The experiment was performed between November, 2006 and January, 2007 in the Laboratorio de Entomología of the Unidad Académica Centro de Ciencias Agrarias of the Universidad Federal de Alagoas, Brazil $\left(9^{\circ} 27^{\prime} \mathrm{S}, 35^{\circ} 27^{\prime} \mathrm{W}\right.$, altitude $\left.127 \mathrm{~m}\right)$. The mean temperature and mean relativity during the experiment were $26.6 \pm 1^{\circ} \mathrm{C}$ and $66.5 \pm 5 \%$, respectively.

In the Beira Rio Farm, located in the city of Batalha (0940'40'S, 3707'29'W, altitude 120 $\mathrm{m})$ we collected engorged females of from cattle of the Zebu breed, naturally infected and with no application of pesticides in more than 30 days. Ticks were collected from the pelvic, inguinal and auricular regions of the cattle, placed in Petri dishes and transported to the laboratory in thermal containers. To reduce the mobility and avoid premature oviposition of the engorged ticks, they were maintained in the laboratory at $3 \pm 2^{\circ} \mathrm{C}$ until the beginning of the experiments.

The bioassays were based on the techniques described by Drummond (1973) and Campos Júnior \& Oliveira (2005); engorged ticks collected no more than 24 hours earlier and in optimum conditions for oviposition were weighed and separated randomly into groups for the treatments. The fungal isolates Fitossan 1, Fitossan 2 and Fitossan 3 of $B$. bassiana were used at concentrations of $10^{7}, 10^{8}$ and $10^{9}$ conidia $\mathrm{mL}^{-1}$ ); the isolates PL 43, UOD and Fitossan 4 of $M$. anisopliae were used at the same concentrations. We used two controls; distilled water + Tween-80 (Polyoxethylene Sorbitan) $0.01 \%$ and distilled water alone, for a total of 20 assays.

All the fungal isolates used in this study are part of the fungal culture library of the Fitossan Laboratory - Asistencia Fitosanitaria y Control Biológico, Ltda. The isolates Fitossan 1, Fitossan 2 and Fitossan 3 of B. bassiana were collected, respectively, from Orthezia praelonga Douglas, 1891 (Hemiptera: Orthezidae), Castnia licus (Drury, 1773) (Lepidoptera: Castniidae) and Cosmopolites sordidus (Germar, 1824) (Coleoptera: Curculionidae), while the isolates of M. Anisopliae were collected from Mahanarva posticata (Stal, 1855) (Hemiptera: Cercopidae).

For multiplication and thinning, the strains were cultivated for 7 days in Petri dishes with potato dextrose, the antibiotic (PDA+A) and $\mathrm{Nujol}^{\circledR}$ mineral oil (previously autoclaved at $120^{\circ} \mathrm{C}$ for 20 
Table 1. Evaluation of the efficiency of control of different treatments on Rhipicephalus (Boophilus) microplus (Canestrini, 1887).

\begin{tabular}{ll}
\hline & Treatments \\
\hline $\begin{array}{c}\text { Beauveria bassiana } \\
\left(\text { conidia } \mathrm{mL}^{-1}\right)\end{array}$ & $\begin{array}{c}\text { Metarhizium anisopliae } \\
\left(\text { conidia } \mathrm{mL}^{-1}\right)\end{array}$ \\
\hline Control & Control \\
Controle+ Tween 80 & Controle + Tween 80 \\
Fitossan 1 (10) & PL43 $(10)^{9}$ \\
Fitossan 1 $(10)^{8}$ & PL43 $(10)^{8}$ \\
Fitossan 1 $(10)^{7}$ & PL43 $(10)^{7}$ \\
Fitossan 2 $(10)^{9}$ & UOD $(10)^{9}$ \\
Fitossan 2 $(10)^{8}$ & UOD $(10)^{8}$ \\
Fitossan 2 $(10)^{7}$ & UOD $(10)^{7}$ \\
Fitossan 3 $(10)^{9}$ & Fitossan 4 $(10)^{9}$ \\
Fitossan 3 $(10)^{8}$ & Fitossan 4 $(10)^{8}$ \\
Fitossan 3 $(10)^{7}$ & Fitossan 4 $(10)^{7}$ \\
\hline
\end{tabular}

minutes). Strains were transferred to similar Petri dishes and cultivated for 7 days in a BOD-type incubator at $26 \pm 1^{\circ} \mathrm{C}$ with a $12 \mathrm{~h}: 12 \mathrm{~h}$ light-dark cycle (Alves, 1998; Alves et al., 1998). Conidial suspensions were prepared by adding $100 \mathrm{~mL}$ of distilled water and $0.01 \%$ Tween- 80 (Polyoxethylene Sorbitan). Conidial densities were estimated in a Neubauer chamber under an optical microscope and then adjusted to concentrations of $10^{7}, 10^{8}$ and $10^{9}$ conidia $\mathrm{mL}^{-1}$.

The viability of the strains was evaluated using two Petri dishes with dextrose agar and antibiotic PDA+A for each treatment. With a Drigalsky spatula we added $0.1 \mathrm{~mL}$ of the suspensions of $10^{7}, 10^{8}$ and $10^{9}$ conidia $\mathrm{mL}^{-1}$. After 24 hours, the percentage of germinated conidia was estimated using an optical microscope, observing 100 conidia per plate.

Engorged female ticks were washed with distilled water, dried on absorbent paper and immersed in $100 \mathrm{ml}$ of fungal suspension for 10 minutes. Beginning 72 hours after treatment, we evaluated daily the percentage mortality, number of eggs, egg weight $(\mathrm{mg})$, percentage eclosion and product efficiency (\%). The percentage mortality (M) was analyzed according to Schneider \& Orelli (Nakano et al. 1981) and the reproductive efficiency (RE) and product efficiency (PE) with the formula of Drummond (1973).

$\mathrm{M}=\%$ Mortality in a treatment- $\%$ Mortality in the control $\mathrm{x} 100$ $100-\%$ Mortality in the control

$$
\begin{aligned}
& \mathrm{RE}=\underset{\text { egg weight } \times \text { \% eclosion }}{\text { Weight of females }} \times 20,000^{1} \\
& \mathrm{PE}=\frac{\mathrm{RE}(\text { control })-\mathrm{RE} \text { (treatment) })}{\mathrm{RE}(\text { control })} \times 100
\end{aligned}
$$

The experimental design was completely randomized with 20 treatments and 5 repetitions. The data were analyzed by analysis of variance and Tukey a posteriori tests using the program Assistat 7.4 (Ferreira 2000).

\section{Results and Discussion}

The viability of the conidia of the isolates was greater than $95 \%$ for all experiments.

Mortality varied from $16 \%$ (water + Tween 80 ) to $100 \%$ (B. bassiana Fitossan 1 with $10^{9}$ and $10^{7}$ conidia $\mathrm{mL}^{-1} ; M$. anisopliae PL 43 with $10^{9}$ and $10^{8}$ conidia $\mathrm{mL}^{-1} ;$ M. anisopliae UOD with $10^{9}$ and $10^{8}$ conidia $\mathrm{mL}^{-1}$ and $M$. anisopliae Fitossan 4 with $10^{9}, 10^{8}$ and $10^{7}$ conidia $\mathrm{mL}^{-1}$ ) during the 21 days of observation (Table 2). Fitossan 1 at $10^{9}$ conidia $\mathrm{mL}^{-1}$ produced $48 \%$ mortality of $B$. bassiana within 4 days and $100 \%$ mortality within 14 days, notably more than the other treatments. Treatment with PL 43 at $10^{8}$ and $10^{9}$ conidia $\mathrm{mL}^{-1}$ produced $60 \%$ and $44 \%$ mortality, respectively, after 11 days, while after 14 days PL 43 at $10^{9}$ conidia $\mathrm{mL}^{-1}$ produced $92 \%$ mortality. These values were greater than the mean mortality of $16 \%$ and $24 \%$ obtained after 21 days in the controls with water + Tween 80 and water, respectively (Table 2), which demonstrates the pathogenic effect of these strains on engorged females of $R$. (Boophilus) microplus.

Overall the mortality of engorged females produced by $B$. bassiana was significantly less than that produced by $M$. anisopliae, comparing the controls with and without Tween 80 and $B$. bassiana Fitossan $2\left(10^{8}\right.$ and $10^{7}$ conidia $\left.\mathrm{mL}^{-1}\right)$ and B. bassiana Fitossan $3\left(10^{7}\right.$ conidia $\left.\mathrm{mL}^{-1}\right)$ (Table 3). This difference may be related to the species and strains of the studied pathogens; these results are similar to those obtained by LOPES et al. (2007). The high activity of M. anisopliae was also found by Kaaya et al. (1996) for the species Amblyomma variegatum (Fabricius, 1794) (Acari: Ixodidae); these authors reported an adult mortality

1 According to Campos Júnior (2005), there are about 20,000 cattle tick eggs in one gram. 
Table 2. Mean ${ }^{1} \pm(\mathrm{PE})$ mortality $(\%)$ of engorged females, number of eggs oviposited, egg weight (g), eclosion (\%) and efficiency of the product (\%) in Rhipicephalus (Boophilus) microplus after treatment with isolates of Beauveria bassiana and Metarhizium anisopliae. Experimental conditions were temperature $26.6 \pm 1{ }^{\circ} \mathrm{C}$ and $\mathrm{RH} 66.5 \pm 5 \%$.

\begin{tabular}{|c|c|c|c|c|c|}
\hline \multirow{2}{*}{$\begin{array}{l}\text { Treatment } \\
\begin{array}{l}\text { Beauveria bassiana } \\
\text { (conidia } \mathrm{mL}^{-1} \text { ) }\end{array}\end{array}$} & \multicolumn{5}{|c|}{$\operatorname{Mean}^{1} \pm \mathrm{PE}$} \\
\hline & Mortality & Oviposition & Eclosion & Egg weight (gr) & $\begin{array}{l}\text { Efficiency of } \\
\text { the product }\end{array}$ \\
\hline Water & $24.00 \pm 10.95 \mathrm{e}$ & $27.20 \pm 0.58 \mathrm{a}$ & $100.00 \pm 0.00 \mathrm{a}$ & $0.40 \pm 0.58 \mathrm{bcd}$ & $0.00 \pm 0.00 \mathrm{~b}$ \\
\hline Water + Tween 80 & $16.00 \pm 11.66 \mathrm{e}$ & $26.80 \pm 0.73 a$ & $100.00 \pm 0.00 \mathrm{a}$ & $0.41 \pm 0.71 \mathrm{bcd}$ & $9.42 \pm 0.71 \mathrm{ab}$ \\
\hline Fitossan $1(10)^{9}$ & $100.00 \pm 0.00 \mathrm{a}$ & $10.80 \pm 0.49 c$ & $90.00 \pm 6.12 \mathrm{a}$ & $0.42 \pm 0.71 b c d$ & $24.62 \pm 0.71 \mathrm{ab}$ \\
\hline Fitossan $1(10)^{8}$ & $96.00 \pm 4, .0 \mathrm{ab}$ & $14.20 \pm 1.11 b c$ & $90.00 \pm 6.12 \mathrm{a}$ & $0.55 \pm 0.51 \mathrm{ab}$ & $14.74 \pm 0.71 \mathrm{ab}$ \\
\hline Fitossan $1(10)^{7}$ & $100.00 \pm 0.00 \mathrm{a}$ & $15.20 \pm 1.28 b c$ & $100.00 \pm 0.00 \mathrm{a}$ & $0.63 \pm 0.51 \mathrm{a}$ & $2.04 \pm 0.49 b$ \\
\hline Fitossan $2(10)^{9}$ & $84.00 \pm 7.48 \mathrm{abc}$ & $1740 \pm 1.29 b$ & $90.00 \pm 10.00 \mathrm{a}$ & $0.64 \pm 0.71 \mathrm{a}$ & $12.77 \pm 0.49 \mathrm{ab}$ \\
\hline Fitossan $2(10)^{8}$ & $56.00 \pm 9.80 \mathrm{~cd}$ & $18.60 \pm 0.98 b$ & $100.00 \pm 0.00 \mathrm{a}$ & $0.64 \pm 0.71 \mathrm{a}$ & $1.01 \pm 0.40 b$ \\
\hline Fitossan $2(10)^{7}$ & $64.00 \pm 11.66 \mathrm{bcd}$ & $19.80 \pm 0.97 b$ & $100.00 \pm 0.00 \mathrm{a}$ & $0.66 \pm 0.31 \mathrm{a}$ & $5.40 \pm 0.32 \mathrm{ab}$ \\
\hline Fitossan $3(10)^{9}$ & $92.00 \pm 14.70 \mathrm{ab}$ & $19.40 \pm 1.78 b$ & $85.00 \pm 10.00 \mathrm{a}$ & $0.63 \pm 0.71 \mathrm{a}$ & $20.42 \pm 0.71 \mathrm{ab}$ \\
\hline Fitossan $3(10)^{8}$ & $96.00 \pm 4.00 \mathrm{ab}$ & $18.00 \pm 2.02 b$ & $100.00 \pm 0.00 \mathrm{a}$ & $0.65 \pm 0.71 \mathrm{a}$ & $7.81 \pm 0.20 \mathrm{ab}$ \\
\hline Fitossan $3(10)^{7}$ & $44.00 \pm 4.90 \mathrm{de}$ & $17.00 \pm 0.95 b$ & $95.00 \pm 5.00 \mathrm{a}$ & $0.69 \pm 0.51 \mathrm{a}$ & $7.27 \pm 0.51 \mathrm{ab}$ \\
\hline \multicolumn{6}{|c|}{$\begin{array}{l}\text { Metarhizium anisopliae } \\
\text { (conídia } \mathrm{mL}^{-1} \text { ) }\end{array}$} \\
\hline PL43 $(10)^{9}$ & $100.00 \pm 0.00 \mathrm{a}$ & $15.00 \pm 0.84 b c$ & $95.00 \pm 5.00 \mathrm{a}$ & $0.31 \pm 0.71 \mathrm{~cd}$ & $31.60 \pm 0.71 \mathrm{a}$ \\
\hline PL43 $(10)^{8}$ & $100.00 \pm 0.00 \mathrm{a}$ & $16.80 \pm 1.01 \mathrm{~b}$ & $100.00 \pm 0.00 \mathrm{a}$ & $0.28 \pm 0.71 \mathrm{~cd}$ & $23.35 \pm 0.71 \mathrm{a}$ \\
\hline PL43 $(10)^{7}$ & $96.00 \pm 0.20 \mathrm{ab}$ & $16.80 \pm 0.66 b$ & $100.00 \pm 0.00 \mathrm{a}$ & $0.28 \pm 0.71 \mathrm{~cd}$ & $24.02 \pm 0.71 \mathrm{ab}$ \\
\hline UOD $(10)^{9}$ & $100.00 \pm 0.00 \mathrm{a}$ & $19.00 \pm 0.45 b$ & $100.00 \pm 0.00 \mathrm{a}$ & $0.41 \pm 0.58 \mathrm{bcd}$ & $14.88 \pm 0.71 \mathrm{ab}$ \\
\hline UOD $(10)^{8}$ & $100.00 \pm 0.00 \mathrm{a}$ & $17.60 \pm 0.60 b$ & $100.00 \pm 0.00 \mathrm{a}$ & $0.38 \pm 0.51 \mathrm{bcd}$ & $7.84 \pm 0.71 \mathrm{ab}$ \\
\hline $\mathrm{UOD}(10)^{7}$ & $92.00 \pm 0.24 \mathrm{ab}$ & $17.20 \pm 1.32 b$ & $100.00 \pm 0.00 \mathrm{a}$ & $0.40 \pm 0.37 \mathrm{bcd}$ & $10.20 \pm 0.71 \mathrm{ab}$ \\
\hline Fitossan $4(10)^{9}$ & $100.00 \pm 0.00 \mathrm{a}$ & $17.60 \pm 0.51 b$ & $100.00 \pm 0.00 \mathrm{a}$ & $0.41 \pm 0.71 \mathrm{bcd}$ & $13.61 \pm 0.71 \mathrm{ab}$ \\
\hline Fitossan $4(10)^{8}$ & $100.00 \pm 0.00 \mathrm{a}$ & $14.40 \pm 1.63 b c$ & $100.00 \pm 0.00 \mathrm{a}$ & $0.24 \pm 0.71 \mathrm{~d}$ & $31.30 \pm 0.71 \mathrm{a}$ \\
\hline Fitossan $4(10)^{7}$ & $100.00 \pm 0.00 \mathrm{a}$ & $17.40 \pm 1.02 b$ & $100.00 \pm 0.00 \mathrm{a}$ & $0.31 \pm 0.71 \mathrm{~cd}$ & $13.04 \pm 0.71 \mathrm{ab}$ \\
\hline
\end{tabular}

1 Means followed by the same letter in a column were not significantly different $(\mathrm{p}>0.05)$ by Tukey's test.

of $37 \%$, while B. bassiana did not cause mortality in the same period. Similar results were obtained by for engorged females of Amblyomma cajennense (Fabricius, 1787) (Acari: Ixodidae); the percentage control of the studied strains of $M$. anisopliae was superior to those of B. bassiana.

The mean number of eggs oviposited was greater for the two controls than for all the treatments. Fitossan 1 at $10^{9}$ conidia $\mathrm{mL}^{-1}$ B. bassiana significantly reduced the oviposition, to 10.8. Egg weight varied from $0.24 \mathrm{~g}$ (M. anisopliae Fitossan 4, $10^{8}$ conidia $\mathrm{mL}^{-1}$ ) to $0.69 \mathrm{~g}$ (B. bassiana Fitossan 3, $10^{7}$ conidia $\mathrm{mL}^{-1}$ ), indicating that the isolates had different action on the females (Table 2). All the isolates of M. anisopliae in the three concentrations studied had lower egg weight, especially Fitossan 4 $\left(10^{8}\right.$ conidia $\left.\mathrm{mL}^{-1}\right)$, which weighed $0.24 \mathrm{~g}$ (Table 2$)$.

There were no significant differences in eclosion rate among the different treatments; the observed values ranged from $85 \%$ to $100 \%$, the lowest value was obtained for engorged females with the isolate B. bassiana using Fitossan 3, $10^{9}$ conidia $\mathrm{mL}^{-1}$. According to Magalhães \& Lima (1991), entomopathogenic fungi do not have the capacity to synthesize enzymes or produce proteases which could make eggs infertile or even retard their metabolism. Evaluating suspensions of $B$. bassiana on eggs and larvae of R. (Boophilus) microplus, Bittencourt et al. (1996) obtained a significant reduction and an increase in larval mortality.

The efficiency of the products evaluated varied from $0 \%$ to $31.60 \%$; the treatments $M$. anisopliae Fitossan PL $43\left(10^{9}\right.$ conidia $\left.\mathrm{mL}^{-1}\right)$ and M. anisopliae Fitossan $4\left(10^{8}\right.$ conidia $\left.\mathrm{mL}^{-1}\right)$ produced the best results in the control of engorged females, since they had the highest efficiency (Table 2).

Comparing all the variables, $M$. anisopliae Fitossan $4\left(10^{8}\right.$ conidia $\left.\mathrm{mL}^{-1}\right)$, for the mortality produced in less time and for the efficiency in the control of $R$. (Boophilus) microplus, may be considered as the strain which produced the best result at lower concentrations. 
Table 3. Cumulative mortality (\%) of engorged females over time for the different treatments. Entomology Laboratory CECA, UFAL, Rio Largo, AL. Experimental conditions were temperature $26.6 \pm 1{ }^{\circ} \mathrm{C}$ and $\mathrm{RH} 66.5 \pm 5 \%$.

\begin{tabular}{|c|c|c|c|c|c|c|}
\hline \multirow{3}{*}{ Treatment } & \multicolumn{6}{|c|}{ Cumulative mortality (\%) } \\
\hline & \multicolumn{6}{|c|}{ Days after treatment } \\
\hline & 4 & 7 & 11 & 14 & 18 & 21 \\
\hline Water & 0 & 7 & 0 & 0 & 12 & 24 \\
\hline Water + Tween 80 & 0 & 7 & 0 & 4 & 4 & 16 \\
\hline \multicolumn{7}{|c|}{ Beauveria bassiana $\left(\right.$ conidia $\mathrm{mL}^{-1}$ ) } \\
\hline Fitossan $1(10)^{9}$ & 48 & 68 & 84 & 100 & 100 & 100 \\
\hline Fitossan $1(10)^{8}$ & 0 & 8 & 60 & 84 & 96 & 96 \\
\hline Fitossan $1(10)^{7}$ & 0 & 0 & 52 & 60 & 88 & 100 \\
\hline Fitossan $2(10)^{9}$ & 4 & 4 & 12 & 44 & 84 & 84 \\
\hline Fitossan $2(10)^{8}$ & 0 & 8 & 12 & 28 & 48 & 56 \\
\hline Fitossan $2(10)^{7}$ & 0 & 0 & 8 & 32 & 44 & 64 \\
\hline Fitossan $3(10)^{9}$ & 4 & 8 & 16 & 20 & 88 & 92 \\
\hline Fitossan $3(10)^{8}$ & 4 & 12 & 16 & 20 & 76 & 96 \\
\hline Fitossan $3(10)^{7}$ & 4 & 4 & 8 & 16 & 28 & 44 \\
\hline \multicolumn{7}{|c|}{ Metarhizium anisopliae $\left(\right.$ conidia $\mathrm{mL}^{-1}$ ) } \\
\hline PL43 $(10)^{9}$ & 4 & 4 & 44 & 92 & 92 & 100 \\
\hline PL43 $(10)^{8}$ & 0 & 0 & 60 & 64 & 96 & 100 \\
\hline PL43 $(10)^{7}$ & 0 & 0 & 8 & 56 & 92 & 96 \\
\hline $\operatorname{UOD}(10)^{9}$ & 0 & 0 & 16 & 16 & 92 & 100 \\
\hline $\mathrm{UOD}(10)^{8}$ & 0 & 12 & 36 & 56 & 68 & 100 \\
\hline $\mathrm{UOD}(10)^{7}$ & 4 & 4 & 16 & 36 & 64 & 92 \\
\hline Fitossan $4(10)^{9}$ & 0 & 0 & 0 & 44 & 100 & 100 \\
\hline Fitossan $4(10)^{8}$ & 4 & 4 & 16 & 88 & 92 & 100 \\
\hline Fitossan $4(10)^{7}$ & 0 & 8 & 36 & 44 & 80 & 100 \\
\hline
\end{tabular}

Bahiense et al. (2007) suggested that lower percentages of control are expected with biological control methods than with methods of chemical control. It is important to note that this difference is compensated, since the objective of biological control is to maintain pests at economically acceptable levels, while protecting the environment and the native enemies of a given pest.

Recently it has become more urgent to develop new methods of microbial control of pests of veterinary importance, since the results so far indicate the high pathogenic potential of entomopathogens to control organisms considered as key pests. Many of these biological agents may increase the efficiency of control in combination with chemical methods due to additive or synergistic effects, thus obtaining a significant reduction in the use of chemical acaricides (Leal et al. 2003). Wenzel et al. (2004) concluded that the products Butox ${ }^{\circledR}$ (deltametrina), Ectomin ${ }^{\circledR}$ (cipermetrina) and Triatóx ${ }^{\circledR}$ (amitraz), in the doses recommended by the manufacturers, are compatible with strain IBCB 66 of B. bassiana for the control of B. microplus.

The population growth of entomopathogenic fungi in an environment depends, among other factors, on the climatic conditions and the type of grass utilized; these factors may have significant importance in the success of biological control (Gauss \& Furlong 2002).

\section{Acknowledgements}

We thank FINEP/SECT/FAPEAL/CNPq for the financial support of this research and for providing student scholarships. We thank the Phytossan Laboratory, (Assistência Fitossanitária e Controle Biológico Ltda) located in Ingenio Sinimbu, in Jequié da Praia, AL, for providing the fungal strains and cooperating in the research. 


\section{Literature Cited}

Alves, S. B.

1998 Fungos entomopatogênicos. In: Alves, S.B. (Ed.). Controle microbiano de insetos. Piracicaba: FEALQ, cap. 11, pp. 289-370.

Alves, S. B., Almeida, J. E. M., Moino Jr, A., Alves, L. F. A. 1998 Técnicas de laboratório In: Alves, S.B. (Ed.). Controle microbiano de insetos. Piracicaba: FEALQ, cap. 20, pp. 637-710.

Athayde, A.C.R.; Ferreira, U.L.; Lima, E.A. De L. A.

2001 Fungos entomopatogênicos: uma alternativa para o controle do carrapato bovino - Boophilus microplus. Biotecnologia Ciência e Desenvolvimento, v. 21, julho/ agosto, pp. 12-15.

Bahiense, T.C.; Bittencourt, V.R.E.P.

2004 Laboratory evaluation of the compatibility and the synergism between the entomopathogenic fungus Beauveria bassiana and deltamethrin to resistant strains of Boophilus microplus. Annals of the New York Academy of Sciences, v. 1026, pp. 319-322.

Bahiense, T.C.; Fernandes, E.K.K.; Angelo, I. Da C.; Perinotto,

W. M. De S.; Bittencourt, V.R.E.P.

2007 Avaliação do potencial de controle biológico de Metarhizium anisopliae sobre Boophilus microplus em teste de estábulo. Revista Brasileira de Parasitologia Veterinária, v. 16 , n. 4 , pp. 243-245,

Basso, L.M. De S.; Monteiro, A.C.; Belo, M.A.De A.; Soares,

V.E.; Garcia, M.V.; Mochi, D.A.

2005 Controle de larvas de Boophilus microplus por Metarhizium anisopliae em pastagens infestadas artificialmente. Pesquisa Agropecuária Brasileira, v. 40, n. 6, pp. 595-600.

Bittencourt, V.R.E.P.; Souza, E.J.; Peralva, S.L.F.S.; Viegas,

E.C.; Alves, S.B.

1996 Avaliação dos efeitos do contato de Beauveria bassiana (Bals.) Vuill. com ovos e larvas de Boophilus microplus, (Canestrini, 1887) (Acari: Ixodidae). Revista Brasileira de Parasitologia Veterinária, v. 5, n. 2, pp. 81-84.

Bittencourt, V.R.E.P.; Mascarenhas, A.G.; Faccini, J.L.H.

1999 Mecanismo de penetração do fungo Metarhizium anisopliae no carrapato Boophilus microplus em condições experimentais. Ciência Rural, v. 29, n. 2, pp. 351-354.

Bittencourt, V.R.E.P.; Massard, C.L.; Lima, A.F.

1994 Ação do fungo Metarhizium anisopliae, em ovos e larvas do Boophilus microplus. Revista Universidade Rural Série Ciência da Vida, v. 16, n. 2, pp. 41-47.

Bittencourt, V.R.E.P.; Souza, E.J.; Peralva, S.L.F.S; Mascarenhas, A.G.; Alves, S.B.

1997 Avaliação da eficácia in vitro do fungo entomopatogênico Beauveria bassiana (Bals.) Vuill. em fêmeas ingurgitadas de Boophilus microplus (Canestrini, 1887) (Acari: Ixodidae). Revista Brasileira de Parasitologia Veterinária, v. 6, n. 1, pp. 49-52.

Campos Júnior, D.A.; Oliveira, P.R.

2005 Avaliação in vitro da eficácia de acaricidas sobre Boophilus microplus (Canestrini, 1887) (Acari: Ixodidae) de bovinos no município de Ilhéus-BA. Ciencia Rural, v. 35 , n. 6 , pp. 1386-1392.
Correia, A.C.B.; Fiorin, A.C.; Monteiro, A.C.; Veríssimo, C.J. 1998 Effects of Metarhizium anisopliae on the tick Boophilus microplus (Acari: Ixodidae) in stabled cattle. Journal of Invertebrate Pathology, v. 71, n. 2, pp. 189-191.

Drummond, R.O.

1973 Boophilus annulatus and Boophilus microplus: laboratory tests for insecticides. Journal of Economic Entomology, v. 66 , pp. $130-133$.

FAO.

2003 Resistência a los antiparasitários: Estado actual com énfasis em América Latina. Roma, 52 p. (Producción y Sanidad Animal).

Ferreira, P.V.

2000 Estatística Experimental Aplicada a Agronomia. 3. ed. Maceió: EDUFAL.

Frazzon, A.P.G.; Vaz, I.S.; Massuda, A.;Vainstein, M.H.

2000 In vitro assessment of Metarhizium anisopliae in isolates to control the cattle tick Boophilus microplus. Veterinary Parasitology, v. 94, n. 1-2, pp. 117-125.

Gauss, C.L.B.; Furlong, J.

2002 Comportamento de larvas infestantes de Boophilus microplus em pastagem de Brachiaria decumbens. Ciência Rural, v. 32, pp. 467-472.

Kaaya, G.P.; Mwangi, E.N.; Ouna, E.A

1996 Prospects for biological control of livestock ticks, Rhipicephalus appendiculatus and Amblyomma variegatum, using the entomogenous fungi Beauveria bassiana and Metarhizium anisopliae. Journal of Invertebrate Pathology, v. 67, n. 3, pp. $15-20$.

Leal, A.T.; Freitas, D.R.J. de; Vaz Jr., I. da S.

2003 Perspectivas para o controle do carrapato bovino. Acta Scientiae Veterinariae, v.31, n. 1, pp. 1-11.

Lopes, R.B.; Alves, S.B.; Padulla, L.E.L.; Pérez, C.A.

2007 Eficiência de formulações de Beauveria bassiana e Metarhizium anisopliae para o controle de ninfas de Amblyoma cajennense (Fabricius, 1787). Revista Brasileira de Parasitologia Veterinária, v.16, n. 1, pp. 27-31.

Magalhães, F.E.P.; Lima, J.D.

1991 Controle estratégico do Boophilus microplus (Canestrini, 1887) (Acarin: Ixodidae) em bovinos da região de Pedro Leopoldo, Minas Gerais, Brasil. Arquivos Brasileiros de Medicina Veterinária e Zootecnia, v. 43, n. 5, pp. 423431.

Mendes, M.C.; Lima, C.K.P.; Prado, A.P. do.

2007 Determinação da frequiência de realização de bioensaios para o monitoramento da resistência do carrapato Boophilus microplus (Acari: Ixodidae). Arquivos do Instituto Biológico, v. 74, n. 2, pp. 87-93.

Nakano, O.; Silveira Neto, S.; Zucchi, R.A.

1981 Entomologia Econômica. Piracicaba: ESALQ, $314 \mathrm{p}$.

Paião, J.C.V.; Monteiro, A.C.; Kronka, S.N.

2001 Susceptibility of the cattle tick Boophilus microplus (Acari: Ixodidae) to isolates of the fungus Beauveria bassiana. World Journal of Microbiology and Biotechnology, v. 17, n. 3 , pp. $245-251$. 
Reis, R.C.S.; Melo, D.R.; Bittencourt, V.R.E.P.

2004 Efeito de Beauveria bassiana (Bals) Vuill e Metarhizium anisopliae (Metsc) Sorok sobre fêmeas ingurgitadas de Amblyoma cajennense (Fabricius, 1787) em condições de laboratório. Arquivos Brasileiros de Medicina Veterinária e Zootecnia, v. 56, n. 6, pp. 788-791.
Wenzel, I.M.; Barci, L.A.G.; Almeida, J.E.M.; Gassen, M.H.; Prado, A.P.

2004 Compatibilidade do fungo Beauveria bassiana com carrapaticidas químicos utilizados no controle de Boophilus microplus (Acari: Ixodidae). Arquivos do Instituto Biológico, v. 71, (supl.), pp. 643-645. 
